\title{
Higher Education in Developing Countries: Financial Aspects in Uzbekistan
}

\author{
Akhmadbek Yusupov, Nodir Jumaev, and Dilshodjon Rakhmonov
}

\begin{abstract}
We conducted this study to assess the impact of non-public payments on the system of higher education. In Uzbekistan, funding for the higher education system is widely used in the form of budgetary funds, student's (parents') own funds and educational loans. In January-February 2017, the survey was conducted in four higher educational institutions of Uzbekistan. They are: Tashkent Institute of Textile and Light Industry, Tashkent Railway Institute, Tashkent Institute of Finance and Tashkent State University of Economics. A total of 288 students participated.

We have identified correlation interactions using the Pearson Chi-Square test. Conclusions on the interdependence or mutual independence of the answers to these questions were formulated.

Index Terms-Higher education, public expenditure, nonpublic payments, education loan.
\end{abstract}

\section{INTRODUCTION}

In recent years, one of the most important and urgent issues facing the country is an expansion of qualified labor force. In this regard, higher education system has become a key driver of locomotive.

In our opinion, it is of particular importance to further strengthen the financial capacities of higher educational institutions. In fact, higher education system has a crucial role to play in providing skilled workforce for economic growth and innovation.

Therefore, in our country there have been undertaken promising measures and have demonstrated a new stage in the coming years. In these processes, fundamental reforms carried out by the state are of a great importance. In particular, it was reflected in relevant priorities of Decree of the President of the Republic of Uzbekistan dd.on February 7, 2017, Decree of the President of the Republic of Uzbekistan "On Strategy for Further Development of the Republic of Uzbekistan" under No. UP-4947. As a result, Decree of the President of the Republic of Uzbekistan "On measures for further development of higher education system" dd.on April 20, 2017, was of a crucial importance. This decision has set a number of innovations, including a gradual increase in acceptance of students by $18 \%$ in 2017 2021 in higher educational institutions.

In addition, the Resolution of the President of the Republic of Uzbekistan dd.on 26 September 2017 "On further improvement of system on targeted training of candidates for higher education institutions" indicates that this issue is especially relevant. This decision was made as follows: "The 2nd and 3rd year students of academic lyceums where the admissions are ceased on 2018/2019 school year, shall

Published on October 15, 2019

Akhmadbek Yusupov is with the Head of High Commission under Cabinet of Ministers, Uzbekistan (e-mail: dilshodrahmon@mail.ru). complete the education in these academic lyceums according to existing curriculum and receive a diploma of academic lyceum graduate in the state standards." Establishment of this regulation may lead to a doubling the number of entrants to universities by 2018 .

As noted above, increase in student enrollment necessitates scientific research on the capacities and financial capacities of host universities. At the same time, econometric study of student tuition and other cost trends, as well as a need to assess and evaluate the impact of their education on outcomes of the learning process shall raise no doubts.

Different experience has been created in foreign countries to finance tuition fees and cover other costs. In our country such as, for example, payment of tuition fees is provided by parents incomes, educational loans of commercial banks, or other similar resources.

\section{LITERATURE REVIEW}

We shall cite the scientific approaches and research of foreign scientists in relation to foreign experience in financing the following higher education systems.

There are three kinds of financing higher in most countries. As Clark [3] noted that European universities have three sources of revenue potentially: government basic support, the support coming from various government entities for research issues and various types of revenue. Kalashnikov (2009) emphasized that three models of financing higher education were formed in last two decades. The first model is related to the formation of the total market within unions. Second one purposed to promote market rules in education funding and last one is vise-versa. These conclusion is different from Clark's and the volume of the latter is more wide than first one. But here should be decided how proportion is significant. Monika Stachowiak-Kudłaa and Janusz Kudła [13] found that the trade-off between the volume and sustainability of public funding that the regulations are expected when the governmental funds are insufficient for financing higher education. As a result, they concluded, private sources need to be increased based on the results of econometric analyses.

On average across OECD countries, at primary to tertiary levels of education combined, public expenditure per student on public institutions (USD 9552 ) is 59\% higher than public expenditure per student on private institutions (USD 5 992).At the same time, The public expenditure per student in tertiary level is three times higher for public institutions (on average USD 12 222) than for private institutions (USD 4
Nodir Jumaev is was with Banking and Finance Academy of the Republic of Uzbekistan (e-mail: njumaev@gmail.com).

Dilshodjon Rakhmonov is with the Banking and Finance Academy of the Republic of Uzbekistan (e-mail: dilshodrahmon@mail.ru). 
136). (Education at a Glance 2016, pp 214).

Although the role of public funds are essential, but the demand for higher education is increasing day by day. At this point of view, public might not cover all people who wants to enroll in tertiary education, due to that scarce funds in government and influence on tax burden.

Most Central and Eastern Europe countries have made transformations in higher education funding, they are: 1) increase of the state funding for higher education; 2) granting of larger autonomy in financial resource management; 3) ensuring of direct correlation between performance results and the allocated funding; 4) promotion of diversification of the sources of finance, as well as establishment of cooperation among research institutions, enterprises and municipalities (Jana Erina and IngarsErins, 2015). In turn, such kind of tasks give universities more independence, but also receive public funds. That's why, public funds have still remained its role in the field of importance in financing higher education.

According to the Concept of Modernization of Russian Education by 2010 the new forms of tertiary education funding would be introduced, particularly education loan and financial aids that provided by state. Though few of high level experts has radically shifted in favour of such modernisation in 2005, by the end of reform percentage of trusted people to modernisation increased more than $90 \%$ (W. John Morgan \& Grigori A. Kliucharev 2012).

Martin Carnoy,IsakFroumin, Prashant K. Loyalka, Jandhyala B. G. Tilak [12] argued that the higher education funding is constructed deeply according to political prism of the state. Hence, BRICs countries could not provide expanses of tertiary education within rapidly growing demand for it due to that scarcity of public funds. To reach global level of higher education countries conducted some reforms that related to funding, especially private fees. China did the most thoroughgoing reforms in its higher education after universities were reopened in the 1970s. Since at that time, state's policy has changed and the share of government contributions reached to 83 percentage of overall funding.

Russia has made enormous transformation of tertiary education that based on modifyingthe legal framework, afterwards government allowed for private universities. Hence, in 2008 Russia was one the highest enrolled percentage of young people country in higher education. Even eight years ago the unprecedented expansion was occurred that practically every young person could get higher education [2]. Simultaneously, there is the need to make the changes in regulating of higher education, particularly with regard to develop and improve the financial and economic system in order to straighten the correlation between growth of investment and quality in tertiary education (InessaGurban, Anastasia Sudakova, 2015). Besides, higher education expansion that fee-based financing composes to enhance the institutional and social stratification of higher education system, reducing social mobility and equality (Anna Smolentseva, 2017).

Andrei B. Ankudinov, MilyaushaKh. Biktemirova, Elvira I. Khairullina [1] conducted the analyses due to Russian Statistics that related to tertiary education. They studied the factors that affects the decision making of an individual to select for certain type of education. During the period of 2005-2011 investments as an impacted factor to higher education remains in positive results. There is an interesting result that in particularly events the more advanced type of education is achieved the lower are financial performance indicators.

David L. Konstantinovskiy [4] concluded that the higher income families children are studying more elite institutions the lower are choosing secondary special (colleges) and primary professional education (vocationaltechnical schools). Youth from particularly family's group select their higher education accordance with the level of income. Researcher has made survey with the relation to a typology that oriented to reflect the importance of education in reaching the life goals. Here the typology are divided to five parts that consists of winners, outsiders, pessimists, 'others' and hopeless. The first four type of group has got their goal to success and education is being taken account as a means to get result, but not 'others'. By no means, hopeless people have their purpose to attain the outcome, therefore they do not see the education as a means achieve upwards. There is the transition to a 'parentocratic' frame in which enrolment in educational institutions of children depends on parents' income and willing.

In the centre of our research are Russia, China and Uzbekistan from CIS (Commonwealth of Independent States) and Asia, of course Uzbekistan is studied as a representative of both sides (they all are representatives for Shanghai Cooperation Organisation, SCO). Besides we use lessons for these countries from advanced economies, especially EU. Most EU countries have their peculiarities in financing. In the last decade of XX century, public funds of some European (e.g., Germany, Denmark, Greece and Luxembourg) countries were under pressure of "free-of-charge" higher education. From the start of current century, privatization and cost sharing occurred. [16]. In Italy, for instance,tuition fees increased with the ratification of Act of Parliament (537/93). This Act influenced on the policies of some states. Firstly, this act decreased the volume of public fund resources of HEIs. Decreasing contribution of public budget, in turn, reduces the amount of taxes to be paid. Secondly, newly accepted Act supported universities to introduce tuition fees independently [15].

Erik Canton, Frank de Jong [5] conducted the research that related demand for higher education in the Netherlands. The expansion higher education was occurred after World War II, in 1999 that if the enrolment rate was 17 percentage of 18 age cohort, fifty years ago it was 3 percentage only. Nowadays, it is also required that as skills are being more and more substantial value based on knowledge in the Netherlands. They performed econometric analyses and found that students are not responsive to tuition fees, but financial support, the enrolment decision are very related to future labour market earning and the alternative wages. The same trends were experienced after 1950 in Belgium. They pointed out whether differences exist between the demand for university and non-university higher education[7]. Within 1953 about 7 percentage of youngsters went on studying tertiary education, now this rate is approximately 47 percentages of them in Belgium. It should be mentioned that demand for tertiary education was studied in the context of consumption and investment. As known above, income and 
relative wage differences dominate in higher education enrolment decisions. Hessel Oosterbeek, Anja van den Broek [6] studied Dutch students' borrowing behaviour of tertiary education that specifically related to higher education funding. They present that a minority number of Dutch students take up education loan from government for their tertiary education. They prefer to have a part-time job especially these jobs are not related to their field of study. Within this matters, it calls for extra years up to 2, to finish their study in the nominal duration of 4 years. That is why Dutch government is seeking ways to promote students taking borrow more and spend more time to study than their part-time job.

\section{DATA COLLECTION}

During January-February, 2017 the survey was conducted in fourhigher education institutes (HEIs). They are Tashkent Institute of Textile and Light Industry(TITLI), Tashkent Institute of Railway Engineers(TashIRE), Tashkent Institute of Finance (TIF) and Tashkent State University of Economics (TSUE). The first two universities teach specialists in the area of engineering (as a technical HEI). The last two are universities of economics. We chose the third year students to performour survey. Overall number of respondents is 288. In Uzbekistan there is difference between tuition fees of both areas of study, feesare higher for economics. That's why we carried out survey within those HEIs. (Table 2.1).

Nowadays major motive for changes is to enhance the financial position of universities. As a matter of fact, in the society higher education is considerable sector to provide skilled workforce and innovations for economic growth. Muller and Gangl (2003) argued that in order to be sustainable higher education has increased crucial, and tertiary qualifications are valuable and has importance for labor market prospects and the quality of life. It should be pointed out, there is a debate how to finance higher education among countries and how we should form of model of financing tertiary education. In turn, for years there has been arisen share of private financing by students (families, parents, education loan and etc.). Countries not only has already introduced tuition fees for enrollment in their public institutions, but also they are trying to provide social equality in higher education.

Table 2.1

Structure of carried out tests

\begin{tabular}{|llll|}
\hline 1. Gender: & Male & Female & \\
\hline 2. Rating score, & 2.1. & $2.2 .71-85$ & $2.3 .86-$ \\
\% & $55-70$ & & 100 \\
\hline 3. How do you fund the tuition fee?
\end{tabular}

\section{How do you fund the tuition fee?}
3.1.Paid by my parents
3.2. I pay it by myself
3.3. I pay it by educational
3.4. I study on state
loan grant/scholarship

4. When you were choosing the educational major, did the cost of tuition fee paid for this major effect your choice?

4.1. No, I have strictly

chosen this major

4.3. I am studying on

recommendation of my

family

5. When your scholarship is not sufficient for covering
your losses, how do you pay your expenses?
$\begin{array}{ll}\text { 5.1. by own funds } & \text { 5.2. with a loan from my } \\ \text { friend }\end{array}$
$\begin{array}{ll}\text { 5.3. with the help of my } & \text { 5.4. My scholarship } \\ \text { parents } & \text { covers it at all }\end{array}$

There is consensus among the scientists that developing countries are thinking about to transfer funding system from public to private as paid by students and their family. That is some countries are focusing on higher education system based on international experience rather than national social constructions [12]. Such kind of expansions in national tertiary education funding are occurred within the globalisation of national economic and culture [11].

In this paper, we analyse how the people are reacting to the changes in tuition fees and the role of government to increase the rate of enrolment rate in a country. In this case, we focus on studying the sources of paying tuition fees and its impact to social inequality and enrolment rate.

Using the information provided in Table 2.2, financial relations of students are examined in the development of extra-budgetary funds in higher education institutions. As a result, higher education institutions will be able to formulate conclusions on impact of tuition fees and daily student expenses.

It was decided that the best method for this investigation was to use (Pearson) Chi-Squaretests. The purpose of test is to check the correlation. As a result we determine whether there is dependence between questions or not. Participated students had to choose at least one answer for per question. So we have nominal variables. We formed cross tabulations to run the measurements. The asymptotic significance (2-sided with $5 \%$ ) of dependence is confirmed if p-value is lower than 0,05 (when null hypotheses (H0) is true). We use computer program Statistical Package for the Social Sciences (SPSS).

Table 2.2

The description of answers of questionnaire

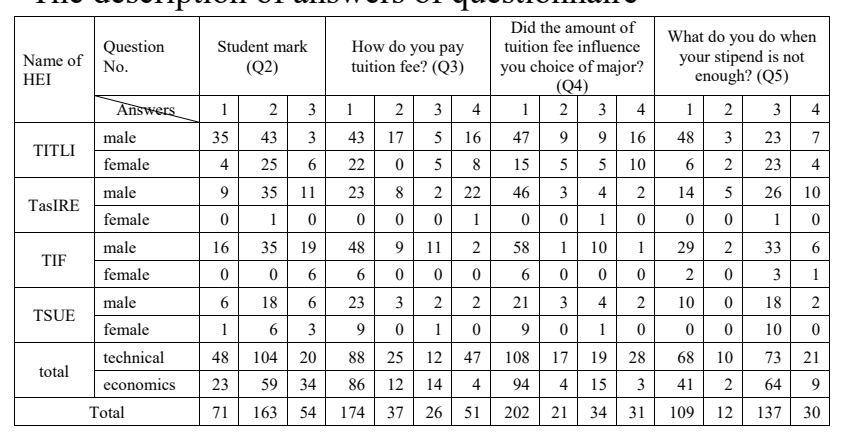

$$
\chi^{2}=\sum_{i} \frac{\left(n_{i}-E_{i}\right)^{2}}{E_{i}}(2.1)
$$

$\chi^{2}$ - chi-square Goodness-of-Fit Test;

$\mathrm{E}_{\mathrm{i}}-\mathrm{n} \pi_{\mathrm{i} 0}$ is the expected number under $\mathrm{H}_{0}$;

$\mathrm{i}$ - number of observations

In addition, participants will be able to analyze an impact of students' responses to rating results by grouping the answers to each question and identifying their mean values. We use the following formula:

$$
\mu=\frac{\sum_{1}^{n} \alpha}{n}(2.2)
$$


$\mu$ - average arithmetic value; $\alpha$ - an answer to Question; $\mathrm{n}$ - number of responses. It is also a standard deviation by using the Statistical Package for Social Sciences (SPSS) compiler software

The first set of analyses highlighted the same distribution answers of question 5 and question 3. This reveals that source of daily expenses are linked to source of tuition fee. In general, parental and individual monetary support are of crucial importance. Although one-third of selfsupported students, who rely on their own income, pay for study themselves parallel, they simultaneously make use of parents payments. Four year education of students not only are paid by parents, but also they need to get money when there is not enough of monthly scholarship. Thus, parental assistance have the highest role in paying for study and expenses(see Table2.3).

Table 2.3

Answer by question $5(\mathrm{Q} 5) *$ Answer by question 3 (Q3)Cross tabulation

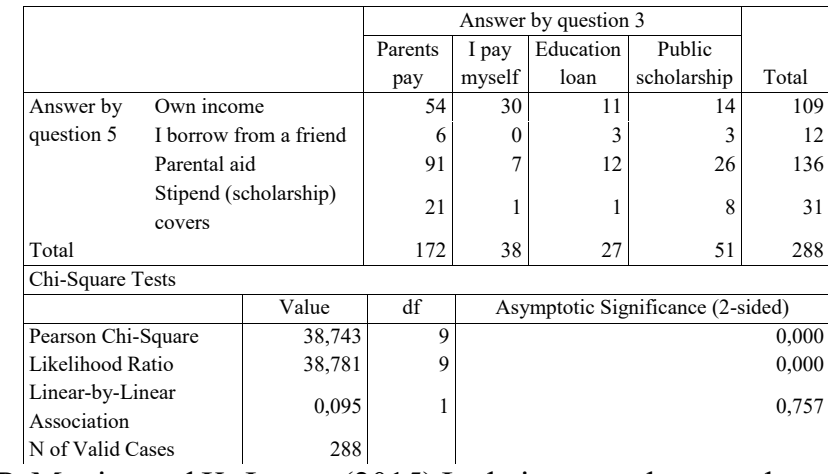

P. Monica and K. Janusz (2015) In their research argue that there is a balance between a size and stability of public funding in cases where public funding fails to finance higher education. As a result, they come to conclusion that the importance of private funds is based on econometric analysis.

Taken together, these findings implicate a role for parental aid. It is worthwhile noting that, Costas Christou, Michael Haliassos [19] emphasized that sources of education fund can be important when making policy decision for tax and other benefits of parents. In Uzbekistan there are many advantages for parents, that pay tuition fees, that is why the following circumstances may impact on the results.

Even though the issue of public funds is important, demand for higher education is increasing day by day. In this context, it may be difficult to cover all expenditures from the state budget because of the high tax burden on covering all those wishing to pursue higher education.

According to Tax Code of the Republic of Uzbekistan, Article 179, part 31, paragraph 1, parents are presented with tax privilege if they make a payment for their offspring study on the basis of salaries (up to age of 27). In this case, for the amount of salary transferred to tuition fee is exempt from income tax of parents. This factor may encourage family to transfer salary of father or mother to fund university studies. Therefore, parents pay attention to higher education financing, otherwise family's expenses may be more.

On the other hand, some students may fail the exam, and if they do not pass in the second (third) chances students cannot go on study anymore in this academic year. It does not matter how many subjects student fails, be it one or several, he/she needs to wait until next year to go on his/her study. In fact, upcoming education year study cost needs to be funded once more. Therefore, parents might make all payments for offspring to complete their education; otherwise parents have excessive payments due to fail the exam. In this point of view, parents' role is significant to get bachelors diploma.

Table 2.4

Correlation among answers of questions

\begin{tabular}{|c|c|c|c|}
\hline & & Q3 & Q5 \\
\hline & $\begin{array}{l}\text { Controlling } \\
\text { variables }\end{array}$ & $\begin{array}{l}\text { Asymptotic } \\
\text { Significance } \\
\text { (2-sided) }\end{array}$ & $\begin{array}{l}\text { Asymptotic } \\
\text { Significance } \\
\text { (2-sided) }\end{array}$ \\
\hline Q4 & & 0,610 & 0,567 \\
\hline Q5 & & 0,000 & \\
\hline \multirow[t]{2}{*}{ Q4 by gender } & Male & 0,884 & 0,527 \\
\hline & Female & 0,014 & 0,675 \\
\hline \multirow[t]{2}{*}{$\mathrm{Q} 5$ by gender } & Male & 0,001 & \\
\hline & Female & 0,073 & \\
\hline \multirow[t]{2}{*}{ Q4 by field } & technical & 0,104 & 0,310 \\
\hline & economics & 0,841 & 0,902 \\
\hline \multirow[t]{2}{*}{ Q5 by field } & technical & 0,001 & \\
\hline & economics & 0,085 & \\
\hline \multirow[t]{4}{*}{ Q4 by HEI } & TITLI & 0,146 & 0,622 \\
\hline & TashIRE & 0,641 & 0,974 \\
\hline & TIF & 0,935 & 0,788 \\
\hline & TSUE & 0,256 & 0,456 \\
\hline \multirow[t]{4}{*}{ Q5 by HEI } & TITLI & 0,025 & \\
\hline & TashIRE & 0,079 & \\
\hline & TIF & 0,053 & \\
\hline & TSUE & 0,643 & \\
\hline
\end{tabular}

Our investigations into this area are still ongoing and seem likely to confirm correlation. The results on gender are compared in terms of significance; there is more relative distribution among males. Interestingly, no any female chose the answer "I pay myself" for question 5. Thus tuition fee of females depends on family fund. We have obtained comprehensive results showing that more than two-thirds of females are provided for daily expenses by parents. This result shows that males are less depended on parents rather than females.

Our further experiments, by fields of study, are consistent with gender measurements. Parental supports are more dominant for economics than technical specialties. This confirms our current findings that there is a relative dependence between source of tuition fee and daily expenses all cases. Our findings would seem to show that females and students of economics correlate well with parental support. Further, the concept of self-support is identical among males and students of technical. There is evidence to support the hypothesis that, students of TSUE rely heavily on the support of their parents. Because, few number of them depend on themselves in paying tuition fee (see Table 2.4).

Our work has led us to the conclusion that the source of tuition fee and daily expenses are the same. In general, there is equal significance of parents and individual support for students who took part in the survey. In turn, the importance of parental aid and individual support depend on gender or study area.

Previous part of analyses have focused on determining irrelativeness between source of paying tuition fees and daily expenses. As a result we went on performing our statistical analyses between answers of questions that are related to cover daily expenses and source of fee. The sample was subdivided on the basis of gender and field of study.

It is interesting to note that there is not dependence between the choice of students' major and source of payment. 
Significant difference was revealed between males and females. All women are compensated, for tuition fees and daily expenses, by family. So females firstly are considering the amount of fees, then they select their speciality. There is a likelihood that the choice could be made for majors with lower tuition fee to ease financial burden for the family. This correlation is worth noting because none of female students make payments by themselves. In common, Uzbek female students don't have part-time jobs during all four years of study.

At the same time, students of technical institutions opted their field due to low amount of tuition fee, which shows a positive correlation between Q4 and Q3 -"due to field of study" (Table 4). Generally, the amount of study costs plays an important role for around a half of respondents.

Our work has led us to conclude that the following factors can impact the aforementioned results:

Females are considering the amount of tuition fee because they are not self-supported, thus they may choose their major due to financial aspects of study area;

The low level of study costs encourages respondents to submit their documents in technical education. The reason for this is that amount of tuition fee of technical fields is lower than economics in Uzbekistan.

There is an evidence, that in Europe tuition fees are defined based on the peculiarities of the specialty. In this regard, Walker \& Zhu [20] argued that social sciences (business, law and medical subjects) are the more attractive field for investment in terms of monetary returns, as opposed to humanities and arts.

Since 2006, implementation of reforms in higher education has risen remarkably. Up to now, the number of students has been determined based on the capacity of HEI. Simultaneously, the amount of tuition fee was also annually established by the government based on stratification of the specialties. According to decree of the President of the Republic of Uzbekistan "About an admission to HEI of Uzbekistan in academic year 2017/2018" on the 5th May 2017 , the number of students rose by 15 percent or from 57907 to 66316. Appropriately the amount of tuition fees were increased radically. From the academic year 2017/2018 on each university can accept extra students that are based on increased fees. On 20th June, 2017, resolution No. 393 of Cabinet Ministers of the Republic of Uzbekistan has been adopted. The new approach was given in detailed explanation and rules. According to this rules first year students need to pay increased charges if they scored 4,0 point lower than the last line of accepted score, but higher 68 .

First group: in relation to normal tuition fee rate from 0 to 1 - 1,5 times; from 1,1 to $2-2,0$ times; from 2,1 to $3-2,5$ times and from 3,1 to $4-3,0$ times.

Second group: This group score is lower than first group, but higher than 68 points. They have to pay more than 10 times ( some universities may be higher 15 times).

The entrance exam for higher education annually takes place on the 1st August. Each applicant needs to answer 108 questions, depending on their field of study. 108 questions are split among three subjects, each one consists of 36 specific question. Applicant may gather 226,8 scores $(36 \times 3,1+36 \times 2,1+36 \times 1,1=226,8)$.

Stratified tuition fee is paid only in the first year of education. From the second year on normal amount of tuition fee is paid.

It should be noted that, the current amount of tuition fee can impact on the choice of applicants (who study technical specialties and females). Such a noticeable trend might create a consequence for applicants of economics (or law, medicine etc.). In the next few years amount of tuition is likely to become a key factor for attending higher education. This component lead us to do further investigations within the next few years.

Table2.5

Econometric analysis of answers given to the 3rd question

\begin{tabular}{|l|r|r|r|r|r|r|r|r|r|}
\hline & \multicolumn{3}{|c|}{ Total } & \multicolumn{3}{c|}{ Male } & \multicolumn{3}{c|}{ Female } \\
\hline Answer by question 3 & Mean & N & $\begin{array}{l}\text { Std. } \\
\text { Dev. }\end{array}$ & Mean & N & $\begin{array}{l}\text { Std. } \\
\text { Dev. }\end{array}$ & Mean & N & $\begin{array}{l}\text { Std. } \\
\text { Dev. }\end{array}$ \\
\hline Parents pay & 2,02 & 172 &, 630 & 1,96 & 136 &, 614 & 2,25 & 36 &, 649 \\
\hline I pay myself & 1,76 & 38 &, 714 & 1,76 & 38 &, 714 & - & - & - \\
\hline Education loan & 1,96 & 27 &, 706 & 1,95 & 21 &, 740 & 2,00 & 6 &, 632 \\
\hline Public scholarship & 1,86 & 51 &, 601 & 1,80 & 41 &, 641 & 2,10 & 10 &, 316 \\
\hline Total & 1,95 & 288 &, 648 & 1,90 & 236 &, 648 & 2,19 & 52 &, 595 \\
\hline
\end{tabular}

There is defined a way in which the tuition fees are paid and impact of students on rating scores. In particular, there was analyzed relationship between the responses given in question 2 and question 3. According to it, students paying tuition fees earn better ratings than other categories of students. At the same time, a standard error is smaller than the sum. It should be noted that payments by themselves are satisfactory and have a good rating. But most of them study with satisfactory results, and all of them are male students. Two-thirds of students are paying tuition fees through their parents' financial support. They also have high scores. None of students answered the tuition fee in the form "I'll pay for it". This can be explained by formation of national values in the country (see Table2.5).

As a continuation of the research, we will study the above indicators in the context of education. It is noteworthy that in addition to the TITF, higher education scores of students in all HEIs, with parental support, are high. This reaffirms the importance of parent's role. Another interesting aspect is that a proportion of students in this category and number of students receiving state grants in the FDI that has allowed to compare them (see Table 2.6).

Table2.6.

Econometric analysis of answers given to the 3rd question of the test in the section of higher educational institutions

In particular, their rating points are not very different. Moreover, according to standard errors, rating scores of students who receive state grants are significantly less than those of undergraduate and graduate students. In addition, students who pay their tuition fee at this institution are significantly higher than other students at this institution. On the contrary, TUI students, who are independent of paying for tuition fees, have a low rating than other students of this university. If you go to TTESI students' responses, you can see that they do not have high scores. In addition, this institution has the smallest rating results of the independent exercise of payments (see Table2.6). 


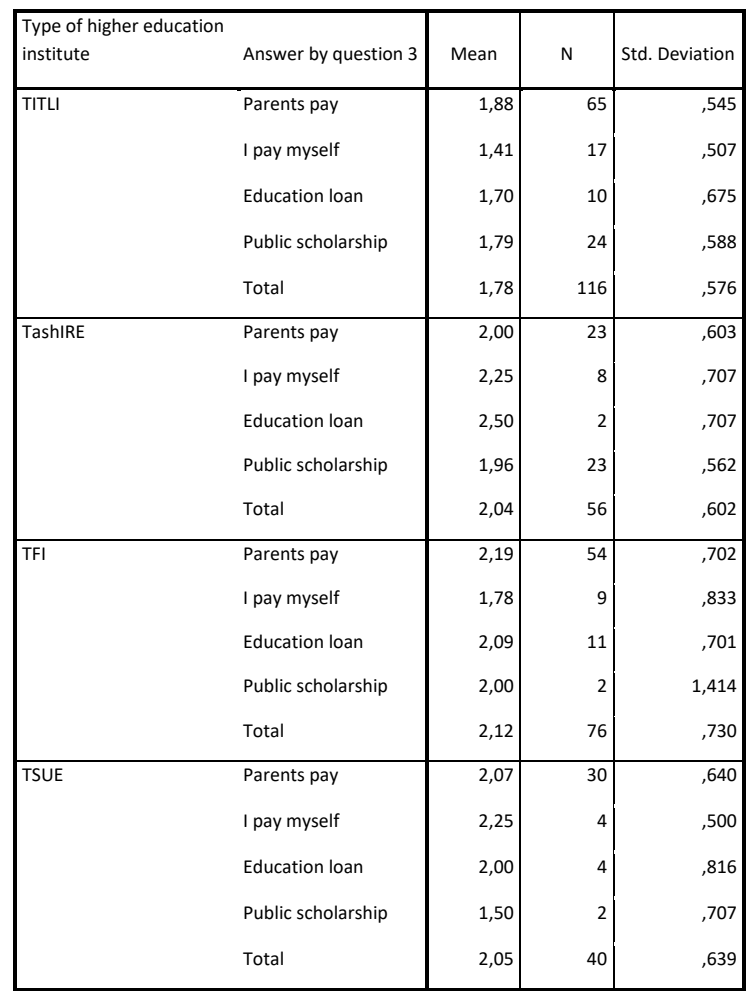

We will continue to analyze trends within the framework of ongoing research. At the same time, we can note that technical rating of students is less than the results of students in economics. Students studying economics are much higher than the rating results of students of the same category with parental support, who pay the tuition fees. On other hand, under the students who make payments independently, rating of students in economics is higher. In general, students in economics have a higher rating score (see Table 2.7).

It should be noted that there is a likelihood that the course will be affected along with the time allocated to it and sustainability of financial resources. For example, final results of students studying in the economic area are high, both for students who pay tuition fees on educational loans. That is, an average for this indicator is 1.83 and 2.07 respectively (see Table 2.7 ).

Table 2.7

Econometric analysis of answers given to the 3rd question of the test in the section of the majors

\begin{tabular}{|ll|r|r|r|}
\hline dummy_econ & Answer by question 3 & \multicolumn{1}{l|}{ Mean } & \multicolumn{1}{c|}{ N } & Std. Deviation \\
\hline tecnical universities & Parents pay & 1,91 & 88 &, 560 \\
& I pay myself & 1,68 & 25 &, 690 \\
& Education loan & 1,83 & 12 &, 718 \\
& Public scholarship & 1,87 & 47 &, 575 \\
& Total & 1,86 & 172 &, 596 \\
\hline economics universities & Parents pay & 2,14 & 84 &, 679 \\
& I pay myself & 1,92 & 13 &, 760 \\
& Education loan & 2,07 & 15 &, 704 \\
& Public scholarship & 1,75 & 4 &, 957 \\
& Total & 2,09 & 116 &, 698 \\
\hline
\end{tabular}

If the impact of tuition fees on level of education has been studied, we will try to see the same tendency within the daily cost. The impact of activities on reducing the daily costs of education can be considerably more than the tuition fee scale. Specifically, if we look at the general trend, most of those who cover current expenses through their own revenues are at least "GOOD". On the contrary, full-time students, receiving financial support possess the higher rating scores in comparison with those who cover the up-to-date coverage reap the costs from other sources (see Table 2.8).

If we look at the results between separate sexes, students who cover their daily income on the basis of their own earnings are significantly less likely to score than students. There are almost the same number of students who cover daily expenses on parental support and income. A number of students with parent support is around 5 times as much as students. Nevertheless, majority of students who cover the costs of their parents' earnings have a higher rating than those in the comparable category. In female students, however, we can see that the opposite is evident (see Table 2.8).

Table 2.8

Econometric analysis of answers given to the 5th question of the test

\begin{tabular}{|l|r|r|r|r|r|r|r|r|r|}
\hline & \multicolumn{3}{|c|}{ Total } & \multicolumn{3}{|c|}{ Male } & \multicolumn{3}{|c|}{ Female } \\
\hline Answer by question 5 & Mean & $\mathrm{N}$ & $\begin{array}{c}\text { Std. } \\
\text { Dev. }\end{array}$ & Mean & $\mathrm{N}$ & $\begin{array}{c}\text { Std. } \\
\text { Dev. }\end{array}$ & Mean & $\mathrm{N}$ & $\begin{array}{c}\text { Std. } \\
\text { Dev. }\end{array}$ \\
\hline Own income & 1,82 & 109 &, 669 & 1,77 & 101 &, 662 & 2,38 & 8 &, 518 \\
\hline I borrow from a friend & 2,00 & 12 &, 739 & 2,00 & 10 &, 667 & 2,00 & 2 & 1,414 \\
\hline Parental aid & 2,02 & 136 &, 614 & 1,97 & 99 &, 614 & 2,16 & 37 &, 602 \\
\hline Scholarship covers & 2,13 & 31 &, 619 & 2,12 & 26 &, 653 & 2,20 & 5 &, 447 \\
\hline Total & 1,95 & 288 &, 648 & 1,90 & 236 &, 648 & 2,19 & 52 &, 595 \\
\hline
\end{tabular}

Hessel Oustrbek, Anja van den Brok (2009), study the trends in Dutch borrowers financing borrowing on higher education. They note that few Dutch students are receiving government loans for higher education. However, although they are not dependent on their own education, they prefer to fund the education through extra work except for study. Under these factors, their education lasts for up to two years, and the four-year education is completed in six years. Therefore, Dutch government is looking for mechanisms to encourage students to receive educational loans from the government and to engage in more study.

We will examine the development of financial resources in the coverage of students' daily expenses at the faculties of higher education. In addition to TSEU students, students who cover daily expenses at their own expense at other HEIs are less likely than the other students in their HEI (see Table2.9). Especially, students of this group receive "satisfactory" ratings in educational institutions. Thus, performing additional activities along with earnings will have an impact on the learning outcomes. At the same time, ratings of students who cover their daily expenses within the framework of their scholarships are highly at the level of their HEIs (Table 2.9).

Table 2.9

Econometric analysis of answers given to the 5th question of the test, in the section of HEIs 


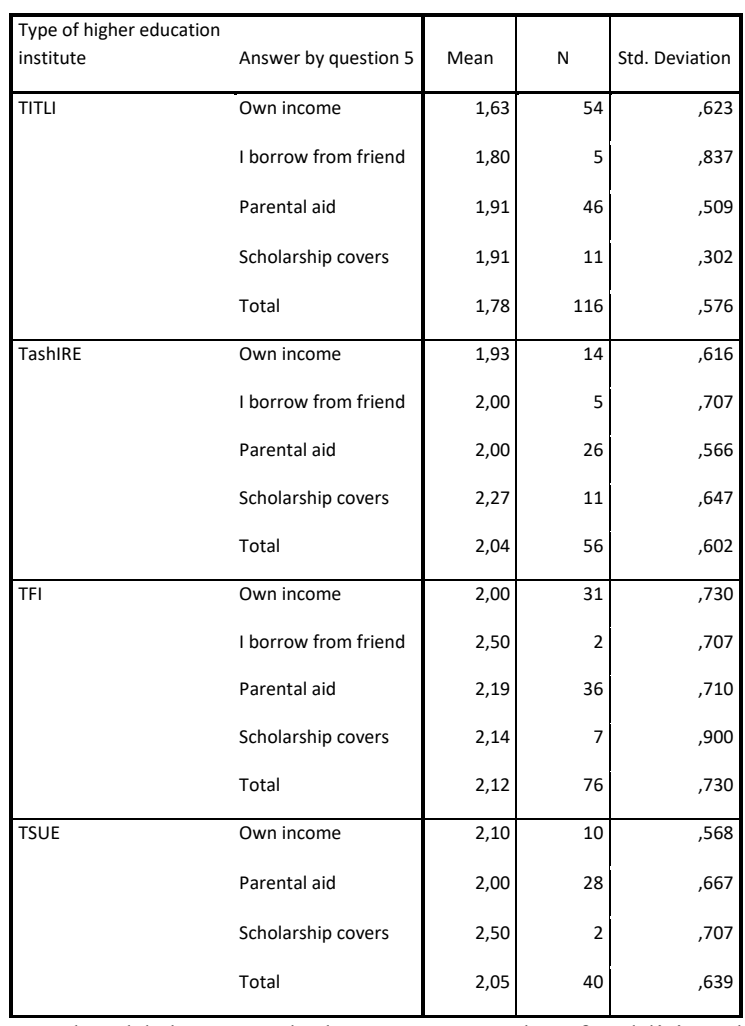

It should be noted that as a result of additional performance during education, education has impacted on quality indicators. Therefore, it is important to improve the mechanism of financing of higher education on the basis of new approaches and create conditions for improving the quality of education.

Table 2.10

Econometric analysis of answer given to the 5th question of the test in the section of majors

\begin{tabular}{|ll|r|r|r|}
\hline dummy_econ & Answer by question 5 & \multicolumn{1}{|c|}{ Mean } & \multicolumn{1}{|c|}{ N } & Std. Deviation \\
\hline tecnical universities & Own income & 1,69 & 68 &, 629 \\
& I borrow from friend & 1,90 & 10 &, 738 \\
& Parental aid & 1,94 & 72 &, 528 \\
& Scholarship covers & 2,09 & 22 &, 526 \\
& Total & 1,86 & 172 &, 596 \\
\hline economics universities & Own income & 2,02 & 41 &, 689 \\
& I borrow from friend & 2,50 & 2 &, 707 \\
& Parental aid & 2,11 & 64 &, 693 \\
& Scholarship covers & 2,22 & 9 &, 833 \\
& Total & 2,09 & 116 &, 698 \\
\hline
\end{tabular}

If we make the above-mentioned analysis in the section of majors, students studying economics record higher scores than technicians. This means that, apart from the financial mechanism, costs may also be affected by rate of education (see Table 2.10).

\section{CONCLUSION}

The test describes how students pay for higher education and how to pay for others. At the same time, it has been attempted to identify practices such as the daily pay-outs and impact of tuition fees on the choice of major.

It should be pointed out no-one of 51 granted students chose their learning field according to recommendations of parents. It can be concluded that, if graduate pupil of colleges or academic lyceums have confidence in their knowledge to enrolment in HEI most of them (about 80 percentages) do not take into account the recommendation of parents. At the same time, half of "independently in opting HEI" students are financial subservient to parents when it is scarcity of fellowship. Thus, this encourages us to have a conclusion that money transfer from parents to children in getting higher education has high impact during four years of studying in HEI.

The current study is able to conclude that:

parents are always ready to assist for their offspring's education;

- although students pay tuition fees themselves a small number of them consider the families' opinion in choosing learning fields;

most engineering students try both to pay tertiary fees and not to receive financial support from parents;

- according to less costs of education nearly independent students study in this field;

among those respondents who have high scores, the number of economists is twice as high as engineers, although the situation is the contrary in paying tuition fees economists are less financially independent compared to engineers.

though students are (rely on - depend on - count on) focusing on parent's income, more than half of them try to earn money to cover their daily expenses when there is lack of scholarship.

\section{REFERENCES}

[1] B. Andrei, Ankudinov, Kh. Milyausha, Biktemirova, I.Elvira. I. Khairullina Investment in higher professional education in Russia: Value-based approach. Procedia - Social and Behavioral Sciences, vol. 152 , pp. $1154-1159,2014$.

[2] A. Smolentseva Universal higher education and positional advantage: Soviet legacies and neoliberal transformations in Russia. Higher Education, vol. 73, pp.209-226, 2017. DOI 10.1007/s10734-016-00099

[3] B.R.Clark Sustaining Change in Universities. Continuities in Case Studies and Concepts. Maidenhead: OpenUniversityPress, 2004.

[4] L.David, Konstantinovskiy Social Inequality and Access to Higher Education in Russia. European Journal of Education, vol. 47, pp. 1, 2012 .

[5] E. Canton, F. Jong The demand for higher education in The Netherlands, 1950-1999. Economics of Education Review, vol. 24, pp. 651-663, 2005.

[6] H. Oosterbeek, A. Broek An empirical analysis of borrowing behaviour of higher education students in the Netherlands Economics of Education Review, vol. 28. pp.170-177, 2009.

[7] Duchesne and W. Nonneman The Demand for Higher Education in Belgium, Economics of Education Review, vol. 17, no. 2, pp. 211-218, 1998.

[8] I. Gurban, A. Sudakova The Development of Higher Education in Russia: an Assessment Methodology. Procedia - Social and Behavioral Sciences, vol. 214, pp.596 - 605, 2015.

[9] J. Erina and I. Erins Assessment of Higher Education Financing Models in the CEE Countries. Procedia - Social and Behavioral Sciences, vol. 177 , pp. $186-189,2015$.

[10] J.W. Morgan and G. A. Kliucharev Higher Education and the PostSoviet Transition in Russia. European Journal of Education, vol. 47, no. 1, 2012.

[11] S.Marginson and I.Ordorika Global hegemony in higher education and research. New York: Social Science Research Council. 2010.

[12] M. Carnoy, I.Froumin, P.K. Loyalka, B.G.Jandhyala, Tilak The concept of public goods, the state, and higher education finance: a view from the BRICs. Higher Education, vol. 68, pp.359-378, 2014.

[13] M. S.Kudła and J. Kudła Financial regulations and the diversification of funding sources in higher education institutions: selected European experiences, Studies in Higher Education, vol. 16, December 2015, DOI: 10.1080/03075079.2015.1119109. 
[14] W.Müller and M. Gangl Transitions from Education to Work in Europe: The Integration of Youth into EU Labour Markets. Oxford: Oxford University Press. 2003.

[15] G. D. Pietro Equality of opportunity in Italian university education: is there any role for social welfare spending? International Journal of Educational Development 23, pp.5-15. 2003.

[16] A.Stamoulas Implementation of the Bologna process goals: on Greek state funding. Higher Education In Europe, vol. 30, no. 1, pp. 41-51. 2005

[17] O.V.Kalashnikov Sources of Higher Education Financing in the Conditions of Innovative Advanced Economy. Finance and credit, vol. 47, no. 383, pp. 73-80, 2009.

[18] X.Rejapov Foreign experience in giving loan to students//Finance and banking, vol.7. pp. 63-72, 2017.

[19] Christou, Costas \& Haliassos, Michael. "How do students finance human capital accumulation?: The choice between borrowing and work," Journal of Policy Modeling, Elsevier, vol. 28(1), pp. 39-51, January 2006.

[20] Walker, Ian \& Zhu, Yu, 2011. "Differences by degree: Evidence of the net financial rates of return to undergraduate study for England and Wales," Economics of Education Review, Elsevier, vol. 30(6), pp.1177-1186. 2011. 